\title{
Sugarwin: A Sugarcane Insect-Induced Gene with Antipathogenic Activity
}

\author{
Ane H. Medeiros, ${ }^{1}$ Flávia P. Franco, ${ }^{1}$ Juliana L. Matos, ${ }^{1}$ Patrícia A. de Castro, ${ }^{2}$ Ludier K. Santos-Silva, ${ }^{3}$ \\ Flávio Henrique-Silva, ${ }^{3}$ Gustavo H. Goldman, ${ }^{2,4}$ Daniel S. Moura, ${ }^{5}$ and Marcio C. Silva-Filho ${ }^{1}$ \\ ${ }^{1}$ Departamento de Genética, Escola Superior de Agricultura Luiz de Queiroz, Universidade de São Paulo, C.P. 83, 13418-900 \\ Piracicaba, SP, Brazil; ${ }^{2}$ Departamento e Ciências Farmacêuticas, Faculdade de Ciências Farmacêuticas, Universidade de \\ São Paulo, Ribeirão Preto, SP, Brazil; ${ }^{3}$ Departamento de Genética e Evolução, Universidade Federal de São Carlos, \\ São Carlos, SP, Brazil; 'Laboratório Nacional de Ciência e Tecnologia do Bioetanol (CTBE), Campinas 13083-970, Brazil; \\ ${ }^{5}$ Departamento de Ciências Biológicas, Escola Superior de Agricultura Luiz de Queiroz, Universidade de São Paulo, C.P. 9, \\ 13418-900 Piracicaba, SP, Brazil
}

Submitted 29 September 2011. Accepted 11 January 2012.

In sugarcane fields, colonization of the stalk by opportunistic fungi usually occurs after the caterpillar Diatraea saccharalis attacks the sugarcane plant. Plants respond to insect attack by inducing and accumulating a large set of defense proteins. Two homologues of a barley wound-inducible protein (BARWIN), sugarcane wound-inducible proteins SUGARWIN1 and SUGARWIN2, have been identified in sugarcane by an in silico analysis. Antifungal properties have been described for a number of BARWIN homologues. We report that a SUGARWIN::green fluorescent protein fusion protein is located in the endoplasmic reticulum and in the extracellular space of sugarcane plants. The induction of sugarwin transcripts occurs in response to mechanical wounding, $D$. saccharalis damage, and methyl jasmonate treatment. The accumulation of transcripts is late induced and is restricted to the site of the wound. Although the transcripts of sugarwin genes were strongly increased following insect attack, the protein itself did not show any effect on insect development; rather, it altered fungal morphology, leading to the apoptosis of the germlings. These results suggest that, in the course of evolution, sugarwinencoding genes were recruited by sugarcane due to their antipathogenic activity. We rationalize that sugarcane is able to induce sugarwin gene expression in response to $D$. saccharalis feeding as a concerted plant response to the anticipated invasion by the fungi that typically penetrate the plant stalk after insect damage.

Plant responses to herbivores and pathogens are complex and modulate the expression of a large number of genes, many of which are believed to play roles in defense (Agrawal et al. 2003). To effectively combat invasion by microbial pathogens and herbivorous insects, plants have evolved sophisticated defensive strategies to perceive the attack by pathogens and insects and to translate this perception into an appropriate defensive response (Dangl and Jones 2001).

Current address for A. H. Medeiros: Universidade Federal de São Carlos, campus Araras, Piracicaba, SP, Brazil.

Corresponding author: M. C. Silva-Filho; Telephone: +55-19 34294442; Fax: +55-19 34336706; E-mail: mdcsilva@usp.br

* The $e$-Xtra logo stands for "electronic extra" and indicates that two supplementary tables and one supplementary figure are published online.
Both herbivore feeding and mechanical damage induce systemic responses that are rapidly propagated throughout the plant and responses that are restricted to the wound site (Kessler and Baldwin 2002). Many plants respond to herbivore attacks by activating defense genes in leaves whose products inhibit the digestive proteases of herbivores and reduce the nutritional quality of the ingested proteins, making the attackers ill (Ryan 1990). The study of the wound response provoked by herbivores began with the seminal work on inducible proteinase inhibitors of tomato plants (Ryan 1968). Since then, several genes that encode wound-inducible proteins (WIN) have been identified in various plant species (Christopher et al. 2004; Ryan 1990; Schilmiller and Howe 2005).

During a search for sugarcane homologues of plant defense genes in the sugarcane expressed-sequence tag (EST) database SUCEST (Vettore et al. 2001), Falco and associates (2001) identified two sugarcane homologues of a protein named barley wound-inducible (BARWIN). BARWIN is a wound- and pathogen-inducible protein that can be isolated from barley seed and leaves (Hejgaard et al. 1992; Svensson et al. 1992). Although the BARWIN domain can be found in association with a chitin-binding domain typical of lectins (Broekaert et al. 1990), a number of proteins have been isolated from plants that show only the BARWIN domain: tobacco PR4 (Friedrich et al. 1991), tomato P2 (Linthorst et al. 1991), WHEATWINs (Caruso et al. 1999), WjAMP-1 from Wasabia japonica (Kiba et al. 2003), ZmPR4 from maize (Bravo et al. 2003), OsPR4 (Agrawal et al. 2003) and OsPR4b (Zhu et al. 2006) from rice, and LrPR4 from Lycoris radiata (Li et al. 2010). The barwin homologues of several plant species have been associated with the plant responses to fungal infection, such as Erysiphe graminis f. sp. hordei in barley (Hejgaard et al. 1992), F. culmorum in wheat (Caruso et al. 1999), Magnaporthe grisea in rice (Agrawal et al. 2003) and L. radiata (Li et al. 2010), F. moniliforme (presently renamed $F$. verticillioides) in maize (Bravo et al. 2003), and Cladosporium fulvum in tobacco (Linthorst et al. 1991). Antifungal activity has been described for BARWIN-like proteins from barley (Hejgaard et al. 1992) and wasabi (Kiba et al. 2003) (which showed activity against both fungi and bacteria) and for recombinant BARWIN-like proteins from wheat (Caruso et al. 2001), maize (Bravo et al. 2003), and rice (Zhu et al. 2006).

In the tropics, sugarcane is an important cash crop cultivated for its stalks, which accumulate high levels of sucrose. This plant contributes to $60 \%$ of the raw sugar produced worldwide, 
with the remaining $40 \%$ coming from the sugar beet. In some countries, a significant part of the sugarcane biomass is used for the production of bioethanol (Grivet and Arruda 2002). In Brazil, the sugarcane borer Diatraea saccharalis (F.) (Lepidoptera: Pyralidae) is the major pest of sugarcane and is responsible for both direct and indirect damage. The indirect damage is caused by microorganisms that gain access to the plant through the openings created by $D$. saccharalis (Ogunwolu et al. 1991). Phytopathogens, such as Colletotrichum falcatum (Went) and $F$. verticillioides (Sacc.) Nirenberg, are widespread in areas of sugarcane borer infestation; together with insects, these fungi form the borer-rot complex.

We report the molecular cloning, subcellular localization, and expression analysis of two sugarcane homologues of barwin, designated herein as sugarcane wound-inducible genes sugarwin1 and sugarwin2. Sugarwin-green fluorescent protein (SUGARWIN::GFP) fusions transiently expressed in onion epidermal cells were detected in the endoplasmic reticulum, transvacuolar strands, and apoplast, thus indicating that SUGARWIN are secreted proteins. Gene expression analyses showed that the induction of sugarwin-encoding genes occurs in response to wounding, attack by $D$. saccharalis, and the application of methyl jasmonate (MJ). The accumulation of sugarwin transcripts is late induced and is restricted to the site of the wound or attack. A recombinant SUGARWIN protein added to the diet of $D$. saccharalis showed no effect on caterpillar development, whereas the same protein incorporated into the growth medium of $F$. verticillioides altered the fungal morphology and caused cell apoptosis. Although our data do not rule out the possibility of sugarwin genes being part of a nonspecific defensive compound storm, we suggest that sugarwin genes may be part of a concerted strategy of plant defense against opportunistic pathogens.

\section{RESULTS}

\section{Isolation of cDNAs encoding two new \\ BARWIN domain-containing proteins.}

Two cDNAs from the sugarcane EST database (Vettore et al. 2001, 2003) were identified: sugarwinl (GenBank accession CA145787) and sugarwin2 (GenBank accession CA138924). The deduced proteins from the isolated cDNAs contain at least two regions: a signal peptide of 32 and 27 amino acids for SUGARWIN1 and SUGARWIN2, respectively, and the BARWIN domain containing 120 and 121 amino acids, respectively. Further analysis revealed that the probable N-terminal signal peptide cleavage site is located between amino acid Q (32 for SUGARWIN1 and 27 for SUGARWIN2) and $\mathrm{Q}$ (Bendtsen et al. 2004). Multiple amino acid sequence alignments of the BARWIN domain from the deduced SUGARWIN1 and SUGARWIN2 proteins revealed a high level of similarities to other HEVEIN-like and BARWIN-like proteins from mono- and dicotyledonous plants (Fig. 1). The structures and domains of these proteins were scrutinized with InterProScan (Quevillon et al. 2005) and revealed, only in the dicotyledonous species, a C-terminal chitin-binding domain, located after the signal peptide, which was followed by an Nterminal BARWIN domain. As with other monocotyledonous species, the SUGARWIN isoforms do not contain the chitinbinding domain, and the proteins fall into a different phylogenetic group (Fig. 2). SUGARWIN1 and SUGARWIN2 showed $73.9 \%$ identity and $80.7 \%$ similarity, whereas the level of SUGARWIN1 similarity to the BARWIN domain from monocot and dicot plants ranged from 80.7 to $93.3 \%$, with identity values as high as $88.2 \%$. The identity of SUGARWIN2 to other BARWIN-like proteins was approximately $75 \%$, with similarity values as high as $81 \%$.
SUGARWIN proteins are secreted through the default secretory pathway.

The amino-terminal regions of SUGARWIN1 and SUGARWIN2 were highly hydrophobic and displayed features similar to signal peptides for translocation to the endoplasmic reticulum (ER). Plasmolized onion epidermal cells transiently expressing SUGARWIN1::GFP and SUGARWIN2::GFP fusion proteins are shown in Figure $3 \mathrm{~A}$ to D. These cells showed green fluorescence in the ER, transvacuolar strands (Fig. 3C), and in apoplast. These results indicate that the chimeric proteins travel from the ER to the cell exterior, following the default secretory pathway. GFP5-ER (mgfp5-ER) (Haseloff et al. 1997) was used as a control for GFP signal retention in the ER (Fig. 3E and F).

\section{Wounding, herbivory, and MJ treatments differentially induce sugarwin genes.}

For the monitoring of the gene expression response after wounding, the plant tissue was separated into two parts that were analyzed separately: the "wounded region" refers to the $2.5-\mathrm{cm}$ region where the damage occurred, and the "unwounded region" represents the upper part of the plant, above the damaged region.

Sugarwin1 and sugarwin2 transcripts began to accumulate 6 $\mathrm{h}$ following $D$. saccharalis attack and continued to accumulate until the last observation, $24 \mathrm{~h}$ later. Transcripts of the two sugarwin isoforms were highly abundant at the wounded region (Fig. 4A and C) and were expressed at low levels at the unwounded region (Fig. 4B and 4D). For example, sugarwinl was 5-fold more highly expressed at the wound site, whereas sugarwin2, after $6 \mathrm{~h}$ of feeding, was 53 times more highly expressed at the wound site than in the unwounded plant parts and, after $12 \mathrm{~h}$ of feeding, this transcript was 192-fold more highly expressed at the wound site. The transcripts of sugarwin2 were much more abundant than those of sugarwinl. At $24 \mathrm{~h}$ after challenge by $D$. saccharalis, the transcript accumulation of both sugarwinl and sugarwin2 increased 15- and 300 -fold at the site of herbivore damage, compared with the control plants at the beginning of the experiment. In the undamaged tissue region, the sugarwin1 and sugarwin2 transcripts presented a threefold increase (Fig. 4B and D). The transcript accumulation reached its peak for both sugarwinl and sugarwin2 after $12 \mathrm{~h}$ of continuous mechanical wounding at the wounded region, while no transcripts accumulated at the unwounded region.

The transcript levels of the sugarcane homologue of Bowman-Birk proteinase inhibitor (BBPI), which was used as a positive control for the mechanical wound and insect treatments, were highly induced by $D$. saccharalis feeding. After $6 \mathrm{~h}$ of insect damage at the wounded region, $B B P I$ transcript accumulation was as high as 84-fold and continued to increase after 24 $\mathrm{h}$ of damage, reaching levels as high as 325 -fold induction. In the unwounded plant parts, $B B P I$ transcript induction was even higher than in the wounded plant parts. In contrast, mechanical wounding resulted in higher BBPI transcript accumulation at the site of the wound (Fig. 4E) than at the unwounded parts of the plant (Fig. 4F), and the levels of induction were much lower than those observed after insect wounding. At the site of mechanical wounding, the highest levels of mRNA accumulation were found $12 \mathrm{~h}$ after wounding was initiated and subsequently decreased.

The effects of MJ and methyl salicylate (MS) were evaluated by spraying both methyl esters onto sugarcane plants. Only MJ induced the transcription of sugarwin- and BBPIencoding genes (Fig. 5A, C, and E; note the differences in scale). MS did not show any effect on sugarwin-encoding genes or $B B P I$ (Fig. 5B, D, and F). 


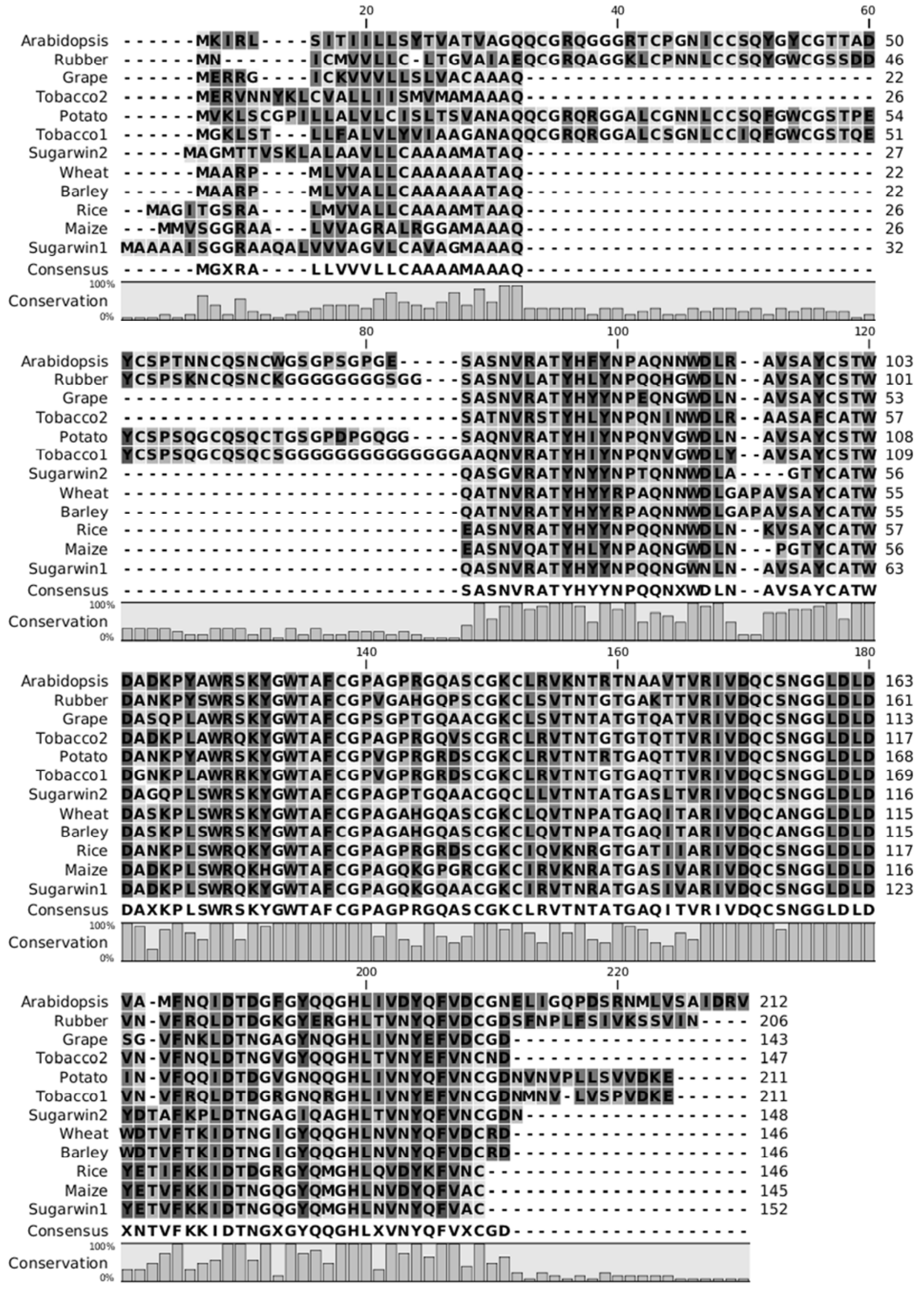

Fig. 1. Amino acid sequence alignment of chitin-binding and barley wound-inducible protein (BARWIN) domain homologues on mono- and dicotyledonous plants: Arabidopsis (GenBank accession P43082), rubber tree (AAO63572), grape (AAC33732), tobacco 1 (AAB29959), tobacco 2 (CAA41437), potato (P09762), sugarcane wound-inducible protein (SUGARWIN)2 (CA138924), wheat (CAA06856), barley (P28814), rice (AAL11444), maize (NP001105464), and SUGARWIN1 (CA145787). The alignment was performed on Muscle (Edgar 2004). The bar graph indicates the residues conservation similarity. The background residue coloring were based on RASMOL colors. 
SUGARWIN protein does not affect

D. saccharalis development.

To test the effect of SUGARWIN proteins on D. saccharalis development, both isoforms of SUGARWIN were produced in Pichia pastoris. Recombinant SUGARWIN1 and SUGARWIN2 proteins with the addition of a histidine tag have expected molecular masses of 14.2 and $16.4 \mathrm{kDa}$, respectively. In total, 151.2 $\mathrm{mg}$ and $1.18 \mathrm{~g}$ of recombinant protein per liter of culture was obtained for SUGARWIN1 and SUGARWIN2, respectively. The SUGARWIN proteins were added to the D. saccharalis diet at a final concentration of $420 \mu \mathrm{g} / \mathrm{ml}$ (30 and $26.3 \mu \mathrm{M}$ for SUGARWIN1 and SUGARWIN2, respectively), and the development of neonate larvae was evaluated after 14 days. No significant difference was found between the control diet (phosphate-buffered saline [PBS]) and the diet with SUGARWIN proteins. By comparison, the positive control, in which soybean proteinase inhibitor was incorporated into the caterpillars' diet, resulted in larvae that weighed as little as $0.0012 \mathrm{~g}$ (Table 1). Larval survival was $95 \%$ on the control diet (PBS) whereas, on the SUGARWIN1 and SUGARWIN2 diets, it was $100 \%$. In the diet containing soybean proteinase inhibitor, only $30 \%$ larval survival was observed (Table 1).

\section{The effect of recombinant SUGARWIN2 on the mycelial morphology and cell death of $\boldsymbol{F}$. verticillioides.}

To test the hypothesis that SUGARWIN proteins are able to affect fungal growth, we exposed $F$. verticillioides 8-h-old germlings to increasing concentrations of SUGARWIN2 (20, 40,80 , and $160 \mu \mathrm{M}$ ) for $16 \mathrm{~h}$ at $25^{\circ} \mathrm{C}$. The SUGARWIN2 protein was used in our experiments because its gene expression in sugarcane plants is nearly 30 -fold higher than that of SUGARWIN1. The viability test shows that SUGARWIN2 treatment at concentrations of 80 and $160 \mu \mathrm{M}$ causes germling cell death (Fig. 6A). To further investigate the mechanism causing cell death, the terminal deoxynucleotidyl transferase dUTP nick-mediated end labeling (TUNEL) assay was used to determine whether SUGARWIN2 induces DNA fragmentation. This assay uses terminal deoxynucleotidyltransferase to label 3'-OH DNA termini with FITC-conjugated dUTP, which can be directly visualized by fluorescence microscopy. After
$16 \mathrm{~h}$ of treatment with $160 \mu \mathrm{M}$ SUGARWIN2, the majority of the hyphae (approximately 80\%) showed TUNEL-positive staining (Fig. 6B, lower panels), whereas the untreated control hyphae showed no staining (Fig. 6B, upper panels). To confirm the effect of SUGARWIN2, differential interference contrast (DIC) and fluorescence microscopy with Calcofluor White analyses were performed. Again, F. verticillioides 8-h-old germlings were exposed to $160 \mu \mathrm{M}$ SUGARWIN2 for 2 to $16 \mathrm{~h}$. The control germlings exposed to PBS showed normal development and clear fluorescent staining of the septa. The germlings exposed to SUGARWIN2 showed dramatic morphological changes (Fig. 7). Approximately 2, 5, 30, 40, and $80 \%$ of these germlings showed abnormalities (such as increased vacuolization, multiple points of fractures in the hyphae, and extensive leaking of intracellular material) (Fig. 7, arrows) when exposed to $160 \mu \mathrm{M}$ SUGARWIN2 for $2,4,6,8$, and $16 \mathrm{~h}$, respectively. Taken together, these results strongly suggest that SUGARWIN2 is affecting the morphogenesis and viability of F. verticillioides, leading to cell death.

\section{DISCUSSION}

Plants are constantly faced with the risk of being attacked by herbivorous insects and pathogenic fungi. Because both insects and fungi are ubiquitous in terrestrial systems, they may encounter each other on the same individual host or may exploit a host that has been altered by previous attack (Denooij et al. 1992). Plant-inducible defenses involve a broad range of proteins and other molecules, the synthesis of which is spatially and temporally controlled (Karban and Baldwin 1997; Walling 2000; Wu and Baldwin 2010). These defense mechanisms appear to be tightly regulated, allowing economy in times of peace and presenting a moving defense horizon to an attacker (Reymond et al. 2004).

In this work, two homologues of the wound- and pathogeninducible barwin gene have been identified in sugarcane. SUGARWIN1 and SUGARWIN2 showed high similarity to the BARWIN domains of monocot and dicot plants (Fig. 1). The BARWIN association with the chitin-binding domain exhibits an intricate and recurrent pattern of evolution. The dicotyledonous plants can be divided into two phylogenetic

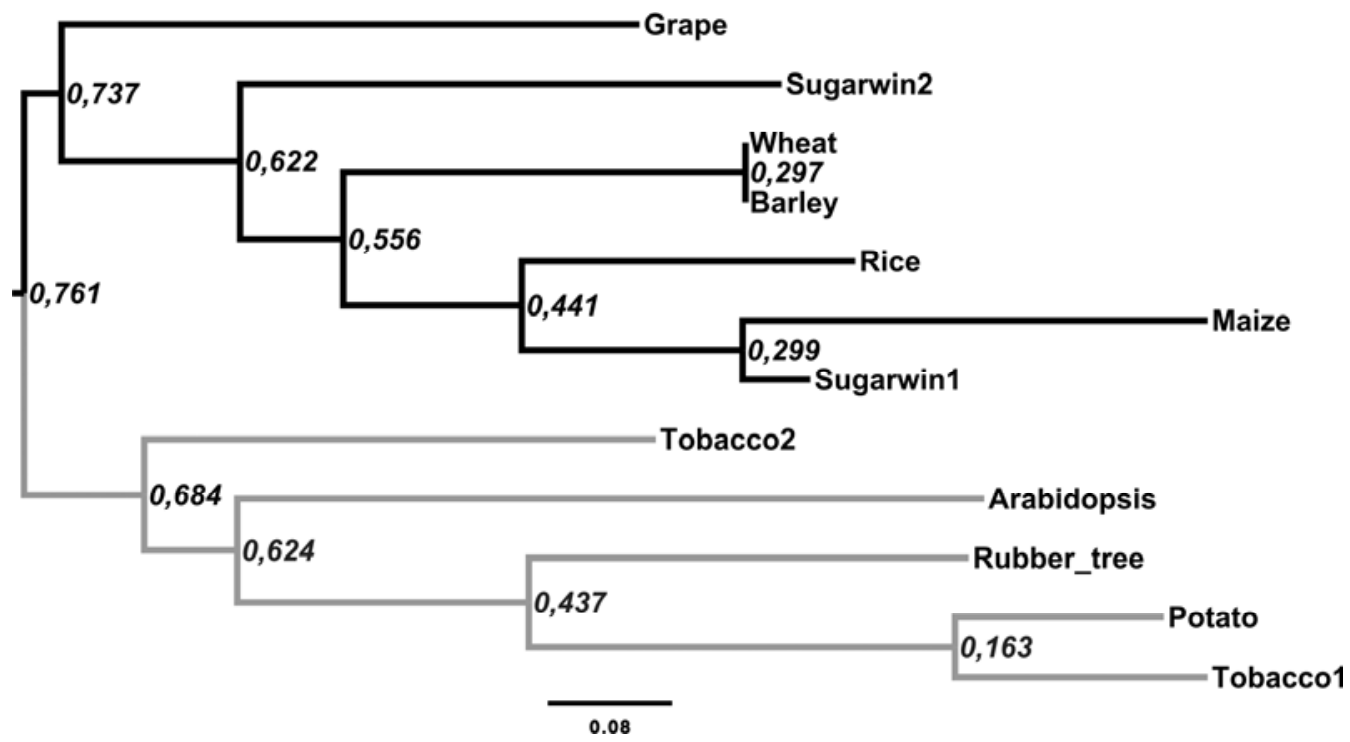

Fig. 2. Maximum likelihood tree of chitin-binding and barley wound-inducible protein (BARWIN) domain sequences. The tree was inferred using the amino acid maximum likelihood feature of PhyML (Guindon and Gascuel 2003). Clades support was given by the approximate likelihood ratio test (aLRT) based on the nonparametric Shimodaira-Hasegawa-like (SH-like) procedure (Anisimova and Gascuel 2006). Scale at bottom of figure indicates the branch length associated with 0.08 substitutions per position. 

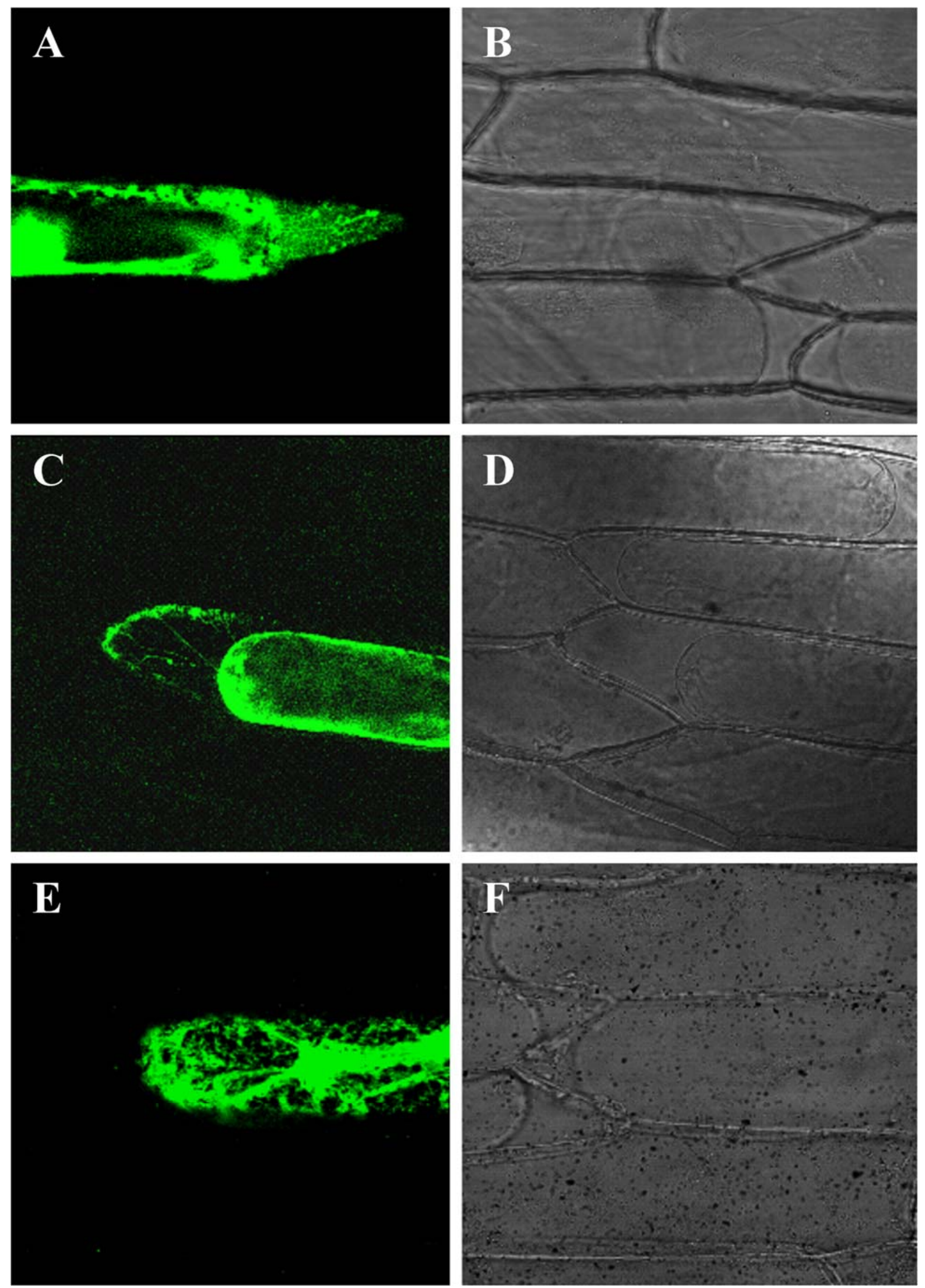

Fig. 3. Confocal laser scanning micrographs of proteins fused to green fluorescent protein (GFP) and transiently expressed in onion epidermal cells. A and B, sugarcane wound-inducible protein 1 (SUGARWIN1); C and D, SUGARWIN2; E and F, the synthetic construct modified GFP protein (mgfp5-ER). Fluorescence and differential interference contrast microscopy were performed using a Zeiss Axiovert 100 M (Carl Zeiss, Thornwood, NY, U.S.A.). 
groups: those that have the hevein domain associated with the BARWIN domain and those that solely have the BARWIN domain (Agrawal et al. 2003; Bravo et al. 2003; Zhu et al. 2006). The monocot homologues of BARWIN, including sugarcane, do not have the BARWIN domain associated with the hevein domain (Fig. 2).

Primary structure analyses of the deduced proteins from both sugarcane BARWIN homologues indicated that they are synthesized as preproteins, with an N-terminal signal peptide that is involved in extracellular secretion. Indeed, SUGARWIN signal peptides fused to GFP and transiently expressed in onion epidermal cells showed that both proteins were targeted to the extracellular space through the secretory pathway (Fig. $3 \mathrm{~A}$ to $\mathrm{D})$. The predicted signal peptide cleavage site, between the first alanine and glutamine residues, and the signal peptide size (32 and 27 amino acids), shows conservation among other BARWIN-like proteins (Agrawal et al. 2003; Caruso et al. 2001; Friedrich et al. 1991; Li et al. 2010; Linthorst et al. 1991; Zhu et al. 2006). The subcellular localization of the SUGARWIN proteins substantiates their antipathogenic function. Phytopathogenic fungi and bacteria are slow-growing organisms that must colonize the extracellular space before penetrating directly or indirectly into the cell lumen. The presence of an antipathogenic protein in the extracellular space would impair microorganism growth and colonization. Thus, this plant strategy appears to be directed toward microorganisms.

The transcript levels of the sugarwin genes accumulated in response to herbivory by $D$. saccharalis (Fig. 4). To our knowledge, this is the first report of the induction of a barwin-like gene by herbivory. The sugarwin genes show a pattern of expression typical of tomato late-wound-induced genes (Ryan

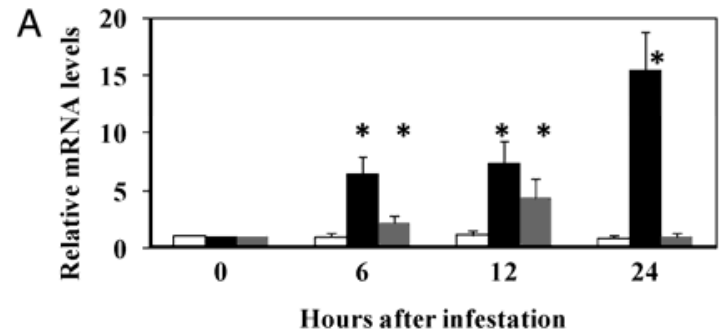

C

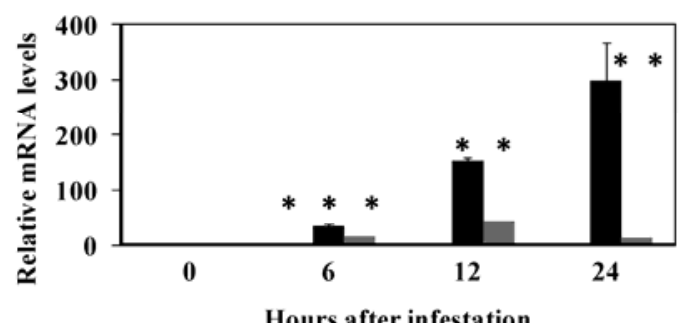

E

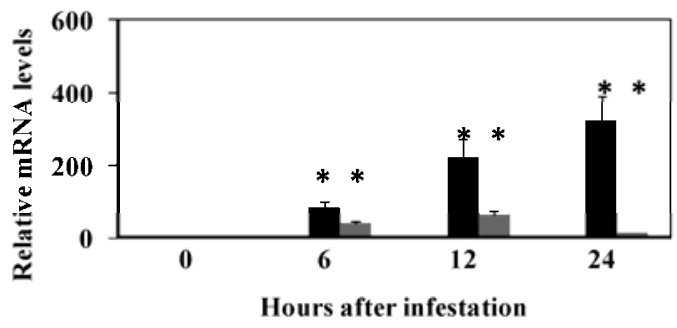

2000). Expression studies have shown a late-inducible pattern of expression for other BARWIN-like proteins: WjAMP mRNAs are significantly increased 24 and $48 \mathrm{~h}$ after inoculation with either Botrytis cinerea or Alternaria alternate (Kiba et al. 2003). Additionally, wounding and inoculation with $F$. moniliforme also induces the expression of ZmPR4 after $24 \mathrm{~h}$ (Bravo et al. 2003). Other monocot plants, such as wheat (Bertini et al. 2006), rice (Agrawal et al. 2003), and barley (Hejgaard et al. 1992), also show induced expression of BARWIN-like proteins after inoculation with distinct pathogenic fungi.

It has been demonstrated that the induction of signaling defenses by one type of intruder may also provide protection (or increased susceptibility) against the attack of another organism. For instance, in Arabidopsis, the spectrum of the herbivore Pieris rapae-induced resistance has been investigated against different pathogens (De Vos et al. 2006); feeding by the herbivore has been shown to significantly reduce the disease caused by the bacterial pathogens Pseudomonas syringae pv. tomato and Xanthomonas campestris pv. armoraciae in caterpillar-damaged tissue, although it was not effective against the necrotrophic fungus A. brassicicola. Another study used different Arabidopsis mutants with impaired jasmonic acid (JA)- and salicylic acid (SA)-dependent defense responses to investigate the impact of pathogen-induced defense responses on herbivore performance (Cui et al. 2002). In the tomato, wounding by Helicoverpa $z e a$ has been shown to induce resistance to the bacterium $P$. syringae pv. tomato (Stout et al. 1999).

Transcripts of sugarwin1 and sugarwin2 were induced at the site of mechanical or insect wounding, whereas they were expressed at very low levels in systemic tissues (Fig. 4). The expression of sugarwin also diminished when the mechanical
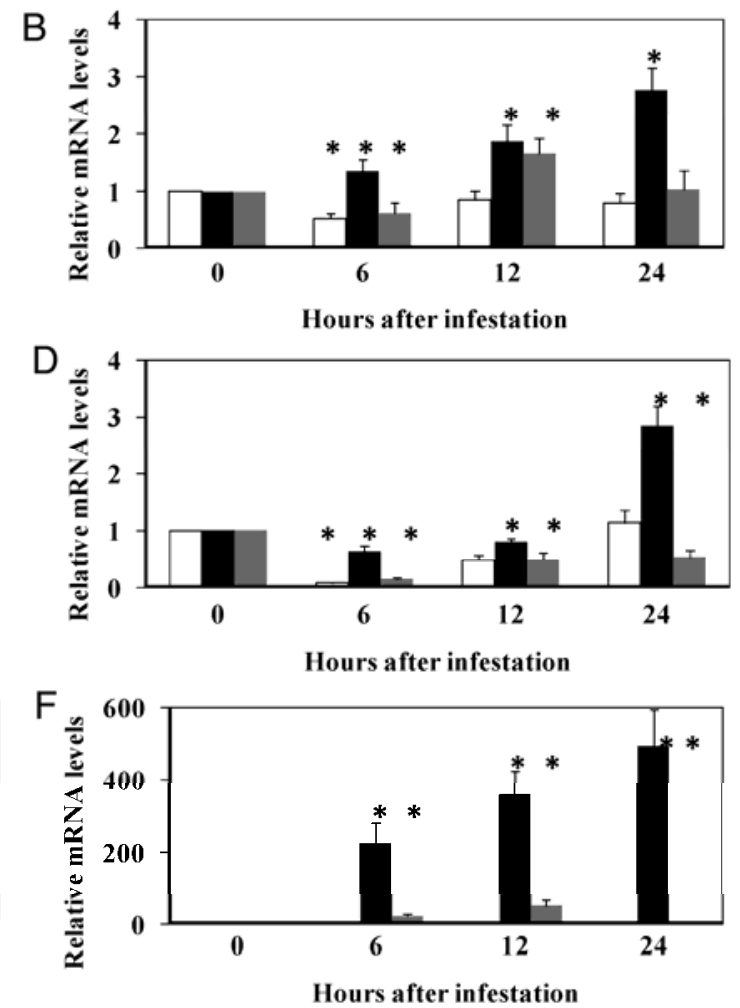

Fig. 4. Expression levels of gene sugarcane wound-inducible 1 (sugarwin1) in the A, wounded and B, unwounded regions of sugarcane; sugarwin2 in the C, wounded and $\mathbf{D}$, unwounded regions; and the Bowman-Birk proteinase inhibitor in the $\mathbf{E}$, wounded and $\mathbf{F}$, unwounded regions. Expression was quantified by real-time quantitative polymerase chain reaction in response to Diatraea saccharalis feeding (black bars) and to mechanical wounding (gray bars) with respect to control expression (white bars). The $\mathrm{x}$-axis indicates the time of analysis (hours after treatment) and the $\mathrm{y}$-axis indicates the fold change in gene expression. Values are the means ( \pm standard error) of the transcripts from three replicates, normalized to the transcript abundance of glyceraldehyde 3-phosphate dehydrogenase. Regulation of expression was calculated with the REST 2008 software (Pfaffl et al. 2002). Asterisks above the bars represent significant differences in comparison with the control at $0 \mathrm{~h}$. 
wounding was halted (after $12 \mathrm{~h}$ ), indicating that the level of expression is dependent on wound infliction. When the plants were exposed to herbivore attack, the transcript levels accumulated over time, likely due to the constant wounding inflicted on the plant. As a positive control for the systemic response, we analyzed the gene expression of the local and systemic inducible inhibitor BBPI. Herbivore attack induced the accumulation of $B B P I$ transcripts at the highest levels in systemic unwounded tissues (Fig. 4E and F). It has been shown for a number of plant families that wounding in the leaves results in the synthesis of defense proteins both at the site of the wound and in the distal systemic leaves (Green and Ryan 1972; Moura and Ryan 2001; Wu and Baldwin 2010). In this study, the high expression level of BBPI observed in the unwounded plant tissues could result in increased protection against chewing insects, because their rate of damage and tissue destruction is very swift. Thus, sugarwin1 and sugarwin 2 transcript accumulation exclusively at the wound site could be related to their roles in plant defense. ZmPR4, through in situ RNA hybridization experiments, has been shown to have mRNA accumulation in the same tissues of fungal-infected germinating embryos (Bravo et al. 2003). The authors suggested that the expression of the ZmPR4 gene could be part of the defense response of germinating maize seed against fungal pathogens. This observation could also be extended to the sugarwin genes.

It has often been observed that, in cases of the sugarcane epiphytotic known as red rot, cultures of microorganisms isolated from the stalk show a blend of organisms that cause rot and wilt (Abbott and Hughes 1961; Khanna and Rafay 1953; Singh et al. 1977). The potential sources of inoculum include the seed cane, or sett, because sugarcane is a vegetatively propagated crop; the soil; or contaminated agricultural implements (Upadhyay et al. 2009). These fungi enter the sugarcane stalk through the root primordia, leaf scars, and bud scales; through wounds caused by cultural operations; and through injuries caused by the sugarcane borer (McKaig 1936; Mian et al. 1969; Upadhyay et al. 2009). Indeed, in sugarcane, attacks by the sugarcane borer, $D$. saccharalis, are often followed by fungi that cause rotting, such as $C$. falcatum and $F$. verticillioides (McKaig 1936; Mian et al. 1969; Ogunwolu et al. 1991). Other examples of insect-fungi association can be found between Fusarium spp. from sugarcane and the stalk borer, Eldana saccharina (Lepidoptera: Pyralidae) (McFarlane et al. 2009) or between $F$. verticillioides and the European corn-borer $O s$ trinia nubilalis (Gatch and Munkvold 2002).

The wounds created by insects permit fungi to invade plants and establish infection sites within the more vulnerable internal tissue (McFarlane et al. 2009). In our experiments, induction of sugarwin genes in unwounded tissue was marginal; therefore, we hypothesize that, if SUGARWIN has antipathogenic activity, it is conceivable that increased levels of sugarwin transcripts at the site of wounds and, therefore, of SUG-

Table 1. Effect of sugarcane wound-inducible proteins SUGARWIN1 and SUGARWIN2 on larval survival and larval weight of Diatraea saccharalis reared for 14 days on corn flour-based diet

\begin{tabular}{lcc}
\hline Treatment & $\begin{array}{c}\text { Larval } \\
\text { survival }(\%)\end{array}$ & $\begin{array}{c}\text { Larvae } \\
\text { weight }(\mathbf{g})^{\mathbf{y}}\end{array}$ \\
\hline${\text { Control diet }(\mathrm{PBS})^{\mathrm{z}}}^{\mathrm{y}}$ & 95 & $0.016 \pm 0.006 \mathrm{a}$ \\
Soybean proteinase inhibitor & 30 & $0.001 \pm 0.001 \mathrm{~b}$ \\
SUGARWIN1 & 100 & $0.015 \pm 0.006 \mathrm{a}$ \\
SUGARWIN2 & 100 & $0.014 \pm 0.006 \mathrm{a}$ \\
\hline
\end{tabular}

${ }^{y}$ Mean values followed by the same letter on the column are not significantly different, according to Tukey test at $5 \%$.

${ }^{\mathrm{z}} \mathrm{PBS}=$ phosphate-buffered saline.
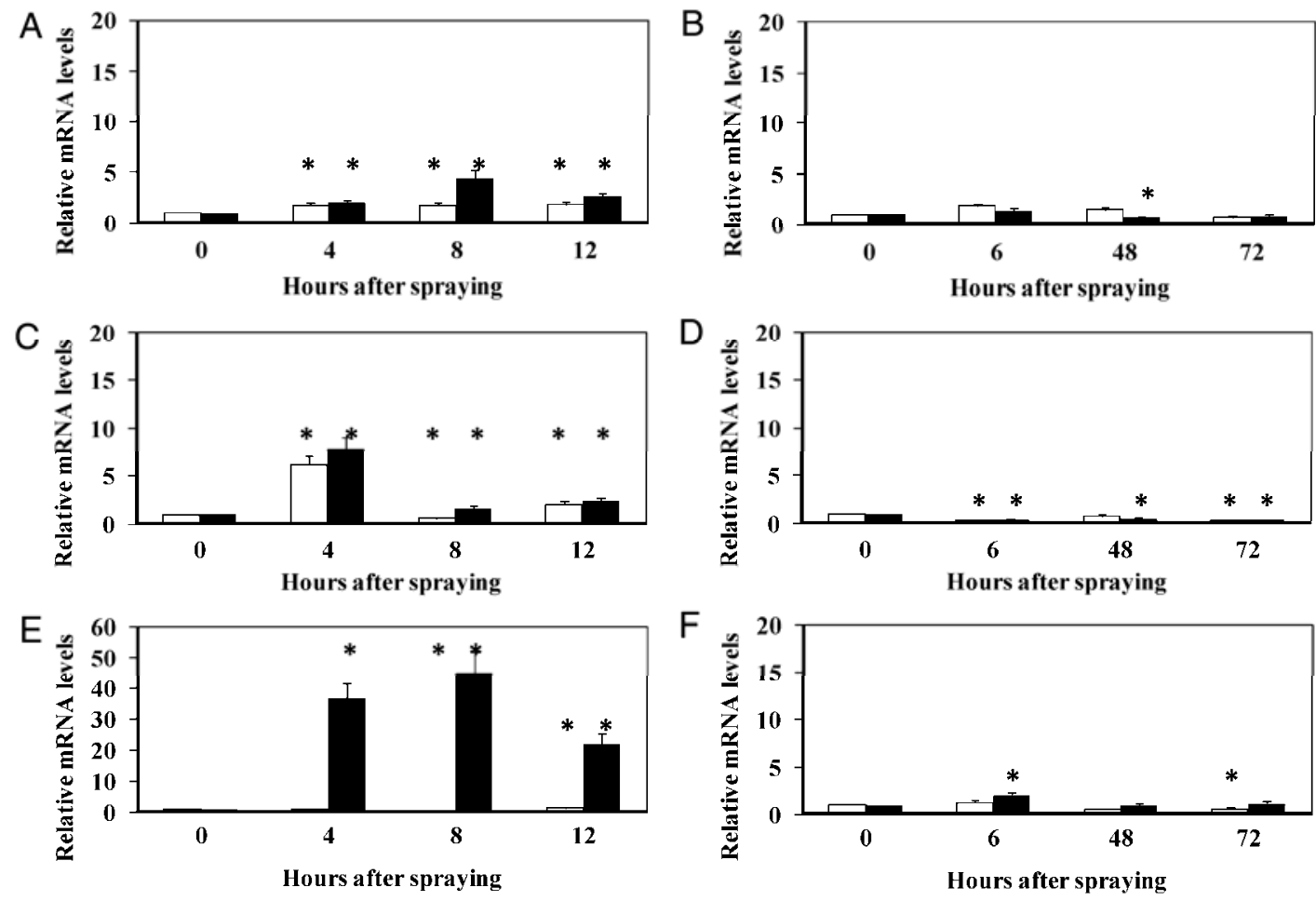

Fig. 5. Expression levels of gene sugarcane wound-inducible 1 (sugarwin1) after A, methyl jasmonate (MJ) and B, methyl salicylate (MS) exposure; sugarwin2 after $\mathbf{C}, \mathbf{M J}$ and $\mathbf{D}$, MS exposure; and the Bowman-Birk proteinase inhibitor after $\mathbf{E}$, MJ and $\mathbf{F}$, MS exposure. Expression levels were quantified by real-time quantitative polymerase chain reaction. The $\mathrm{x}$-axis indicates the time of analysis (hours after treatment) and the y-axis indicates the fold change in gene expression. Values are the means ( \pm standard error) of the transcripts from three replicates, normalized to the transcript abundance of glyceraldehyde 3 phosphate dehydrogenase. The regulation of expression was calculated with the REST 2008 software (Pfaffl et al. 2002). Asterisks above the bars represent significant differences in comparison with the control at $0 \mathrm{~h}$. 


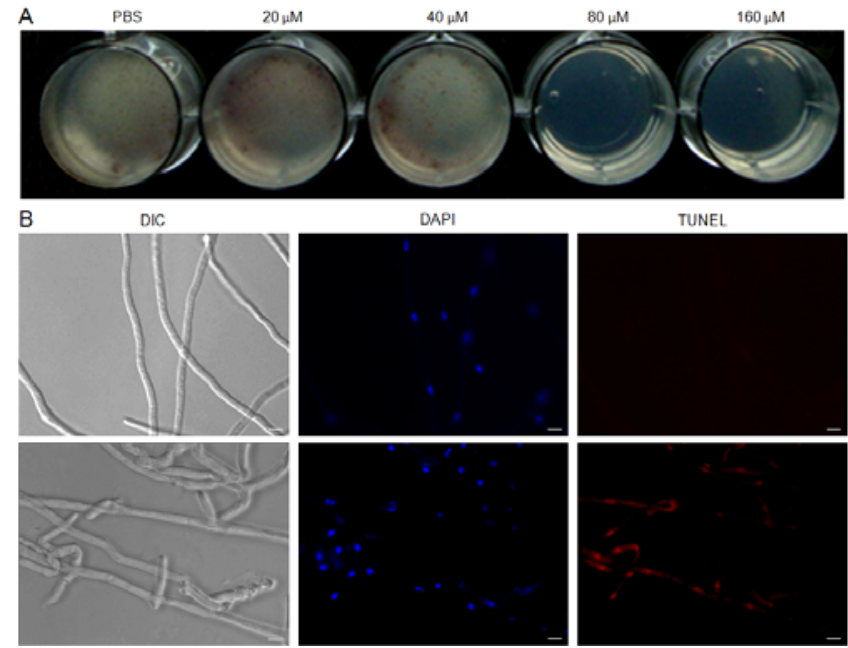

Fig. 6. Effects of sugarcane wound-inducible protein 2 (SUGARWIN2) on cell death in Fusarium verticillioides. A, Viability test of $F$. verticillioides germlings. F. verticillioides germlings were treated with different concentrations of SUGARWIN2 $(20,40,80$, and $160 \mu \mathrm{M})$ for $16 \mathrm{~h}$. Later, the samples were transferred to new plates containing a solid potato dextrose medium and incubated at $25^{\circ} \mathrm{C}$ for another $36 \mathrm{~h}$. B. The terminal deoxynucleotidyl transferase dUTP nick-mediated end labeling (TUNEL) assay for SUGARWIN-treated $F$. verticillioides germlings. F. verticillioides germlings grown in the absence of SUGARWIN2 were either exposed to phosphate-buffered saline (PBS) (upper panel) or grown in the presence of 160 $\mu \mathrm{M}$ SUGARWIN2 (lower panels) for $16 \mathrm{~h}$ at $25^{\circ} \mathrm{C}$. Germlings were then fixed and double-stained with 4',6-diamidino-2-phenylindole (DAPI) and TUNEL. Bars represent $5 \mu \mathrm{m}$.
ARWIN proteins, could decrease the likelihood of colonization by fungi. Altogether, the late-inducible pattern of expression, the exclusive expression of sugarwin mRNA at the wound site, and the extracellular localization of the mRNA support the antipathogenic activity of SUGARWIN proteins.

Plant defenses against pathogens and insects are differentially regulated by cross-communicating signaling pathways in which SA, JA, and ethylene play key roles (Duby et al. 2001; Wu and Baldwin 2009). In general, it can be stated that JA signaling is crucial for protection against herbivore attack (Lukaszewicz et al. 1998; Scott et al. 1999) and appears to mobilize antimicrobial defenses that are predominantly effective against necrotrophic pathogens, whereas the SA-mediated defense response is effective against biotrophic fungi, bacteria, and viruses (Pompermayer et al. 2003). Barwin-like genes have also been reported as being induced by treatment with hormone elicitors. ZmPR4 mRNA accumulates after MJ treatment (Bravo et al. 2003). In tobacco, PR4 is induced 4 days after spraying plants with SA (Linthorst et al. 1991). In rice, OsPR4 is induced by MJ and abscissic acid (Agrawal et al. 2003). The wheat $w P R 4$ ef gene is induced by JA and SA treatment (Howe et al. 1996). In sugarcane, the transcription of the sugarwin genes was induced after treatment with MJ but not with MS (Fig. 5A and B), substantiating the pattern of an insect- and woundinducible gene rather than the pattern suggested by its antipathogenic activity.

We tested a concentration of recombinant proteins in the caterpillar diet that was greater than the endogenous levels found in other plant species (Kiba et al. 2003; Svensson et al. 1992), and
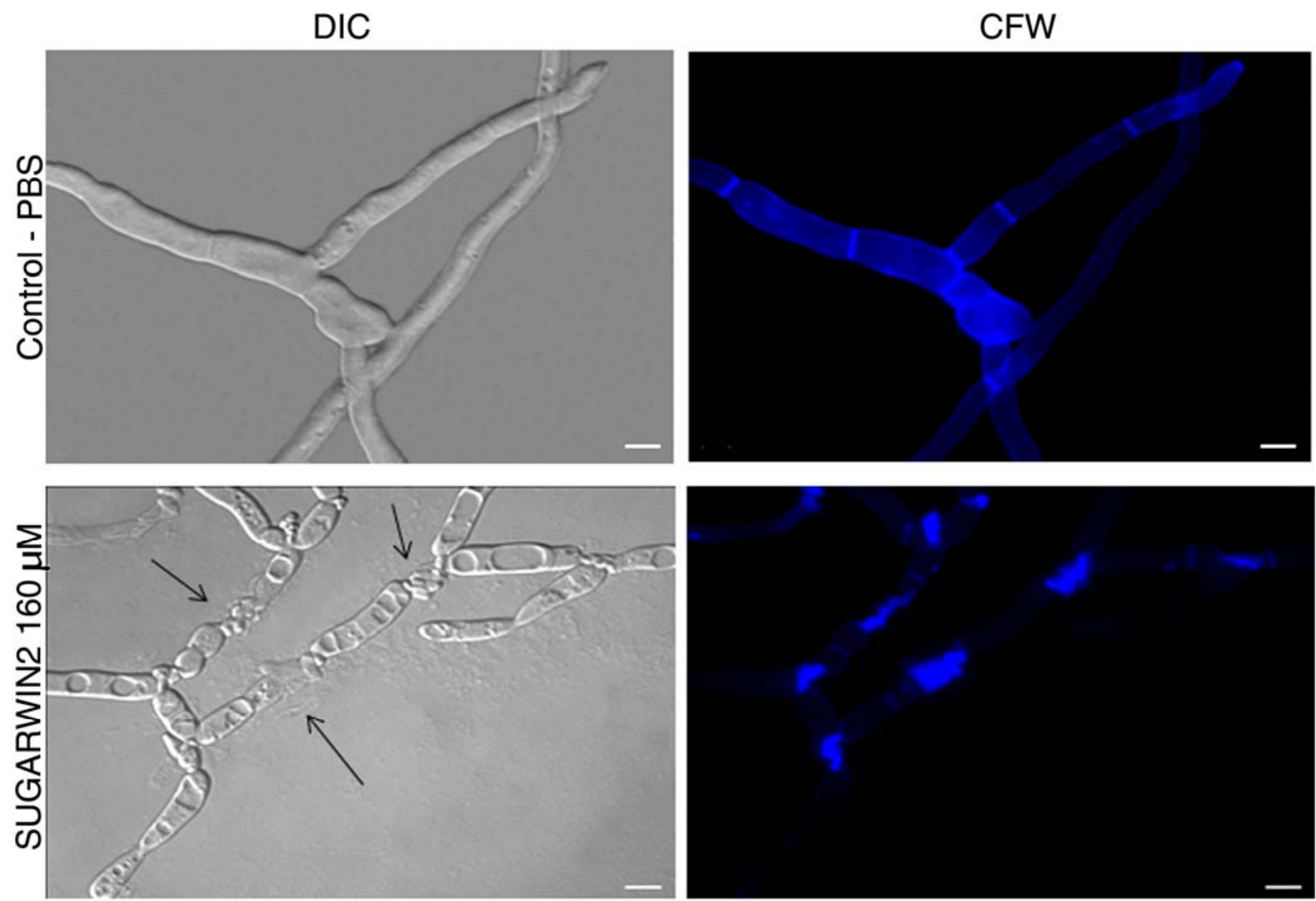

Fig. 7. Effects of sugarcane wound-inducible protein 2 (SUGARWIN2) on the hyphal morphology of Fusarium verticillioides. F. verticillioides germlings grown in the absence of SUGARWIN2 with $16 \mathrm{~h}$ of exposure to phosphate-buffered saline (PBS) at $25^{\circ} \mathrm{C}$ were used as a control for $F$. verticillioides germlings grown in the presence of $160 \mu \mathrm{M}$ SUGARWIN2 for $16 \mathrm{~h}$ at $25^{\circ} \mathrm{C} . \mathrm{CFW}=$ Calcofluor White. Bars represent $5 \mu \mathrm{m}$. 
this treatment had no effect on $D$. saccharalis life history parameters (larval survival and larval weight). Although our minimal concentration of SUGARWIN protein that showed an effect on fungal growth is greater than the concentration used in previous experiments with other BARWIN proteins (Caruso et al. 2001; Bravo et al. 2003; Zhu et al. 2006), the SUGARWIN proteins may have experienced a decrease in their activity due to the added histidine tag. However, we demonstrated major alterations in the morphology of $F$. verticillioides hyphae when SUGARWIN2 recombinant protein was incorporated into the liquid medium. The hyphae exhibited visible abnormalities, such as a twisted appearance, and a TUNEL assay showed that the protein induced DNA fragmentation (Figs. 6 and 7).

Previous in vitro recombinant protein studies have attributed antifungal properties to BARWIN-like proteins (Bravo et al. 2003; Caruso et al. 2001; Zhu et al. 2006). Indeed, in our study, we showed an effect on fungal growth and hyphal biology which is likely to be part of the plant defense against biotrophic stressors. SUGARWIN proteins are involved in fungal cell wall disruption, leading to the leakage of intracellular material and eventual fungal cell death. The high level of similarity of SUGARWIN proteins to other BARWIN-like proteins with antipathogenic activities also suggests that the antifungal activity is conserved among proteins containing the BARWIN domain. Plants respond to insects and pathogens by means of a myriad of specific and nonspecific compounds. Usually, nonspecific responses are constitutive, and induced responses show different levels of specificity. Our data do not exclude sugarwin genes from being part of a set of nonspecific responses; however, their antipathogenic activity and the lack of an effect against the caterpillars support the hypothesis that these genes may be expressed as part of an orchestrated response against pathogens that is triggered by herbivores.

\section{MATERIALS AND METHODS}

\section{Subcellular localization of SUGARWIN1 and SUGARWIN2.}

The server SignalP 3.0 (Bendtsen et al. 2004) was used to predict the peptide cleavage site of SUGARWIN1 and SUGARWIN2. The primers contained restriction sites for cloning into the vector EN50PMA4-3K-GFP (Duby et al. 2001). The plasmid pBIN 35S-mGFP5 (Haseloff et al. 1997) was used as an ER control. The identities of the constructs were confirmed by nucleotide sequencing. The constructs pBIN 35S-mGFP5, SUGARWIN1::GFP, and SUGARWIN2::GFP were delivered into onion epidermal cells using tungsten particle bombardment, as previously reported (Lukaszewicz et al. 1998). The tungsten particles were accelerated using a PDS1000/He Biolistic Particle Delivery System (Bio-Rad, Munich) with rupture discs of $1,100 \mathrm{psi}$ under an $\mathrm{Hg}$ pressure of 28 in. After bombardment, the cells were allowed to recover for 18 to $22 \mathrm{~h}$ at $22^{\circ} \mathrm{C}$ in continuous light. The bombarded peels were bathed in $20 \mathrm{mM}$ MOPS ( $\mathrm{pH} 7.0$ ) buffer for $4 \mathrm{~h}$, according to Scott and associates (1999), and plasmolyzed for $10 \mathrm{~min}$ with $0.5 \mathrm{M}$ mannitol prior to visualization. The fluorescence and DIC microscopy were performed using a Zeiss Axiovert 100 $M$ equipped with $\times 25$ and $\times 40$ water and $\times 100$ oil-immersion lenses (Carl Zeiss, Thornwood, NY, U.S.A.).

\section{Plant and insect materials and treatments.}

The sugarcane plantlets and $D$. saccharalis larvae were provided by the Centro de Tecnologia Canavieira, Piracicaba, SP, Brazil. The sugarcane one-eyed seed sets ('SP80-3280') were planted in 200-ml plastic cups containing a commercial planting mix (Plantmax, Eucatex, São Paulo, Brazil) and cultivated in a greenhouse for 20 days under natural light condi- tions, a temperature of $30 \pm 5^{\circ} \mathrm{C}$, and $40 \pm 10 \%$ relative humidity. The $D$. saccharalis larvae were reared on an artificial diet (Pompermayer et al. 2003) and maintained at $25 \pm 4^{\circ} \mathrm{C}$ and $60 \% \pm 10 \%$ relative humidity with a photophase of $14 \mathrm{~h}$.

To monitor sugarwinl and sugarwin2 transcript accumulation in response to insect attack, third- to fourth-instar larvae were starved for $24 \mathrm{~h}$ prior to being transferred individually to the leaf roll of a sugarcane plantlet. The leaf roll is the preferred entrance site of $D$. saccharalis. The control plants were left unattacked. For the mechanical wounding, the leaf roll was pierced with fine tweezers every hour for $12 \mathrm{~h}$. Plant material was collected at $0,6,12$, and $24 \mathrm{~h}$ and immediately frozen in liquid nitrogen. Three replicates of four plantlets were used for each time point.

For evaluation of the sugarcane response to the phytohormones MJ and MS, 20-day-old sugarcane plantlets were sprayed with $0.2 \mathrm{mM}$ MJ (Bedoukian Research Inc., Danbury, CT, U.S.A.) and $5 \mathrm{mM}$ MS (Sigma-Aldrich, St. Louis) in $0.02 \%$ ethanol diluted with $0.125 \%$ Triton X-100 (Sigma-Aldrich). The control plants were sprayed with the same solution without the phytohormones. The control and treated plants were incubated separately in hermetically sealed plastic boxes, each containing an open jar of $10 \mathrm{~N} \mathrm{NaOH}\left(\mathrm{CO}_{2}\right.$ trap) (Howe et al. 1996). Plant material was collected and immediately frozen in liquid nitrogen at $0,4,8$, and $12 \mathrm{~h}$ after spraying with $\mathrm{MJ}$ and at 0,6 , 48, and $72 \mathrm{~h}$ after spraying with MS. Three replicates of four plantlets were used for each time point. The MJ and MS experiments were repeated two times each.

\section{RNA isolation and cDNA synthesis.}

The total RNA of the sugarcane tissue was isolated with TRIZOL reagent (Invitrogen, Carlsbad, CA, U.S.A.), according to the manufacturer's instructions, followed by DNA removal by treatment with 2 units of RNase-free DNAse I (Fermentas, Vilnius, Lithuania) for $20 \mathrm{~min}$ at $37^{\circ} \mathrm{C}$. To remove any traces of DNA or DNAse that might interfere with the RNA quantification, the RNA was re-extracted with TRIZOL reagent. The total RNA was quantified, and the quality was checked by spectrophotometer and agarose gel electrophoresis. First-strand synthesis was performed in a total volume of $20 \mu \mathrm{l}$, using $2 \mu \mathrm{g}$ of total RNA, $2.5 \mu \mathrm{M}$ poly (dT) primer, and $1 \mu$ of reverse transcriptase, according to the manufacturer's instructions (Improm-II Reverse Transcriptase; Promega Corp., Madison, WI, U.S.A.).

\section{Real-time polymerase chain reaction $(\mathrm{PCR})$ gene expression and data analysis.}

Real-time quantitative (q)PCR was performed using the Rotor Gene 3000 machine (Corbett Life Science, Sydney, Australia) and SYBR Green I chemistry (Platinum SYBR Green qPCR SuperMix-UDG; Invitrogen). Gene-specific primers were designed using OligoPerfect (Invitrogen), and the primer specificity was confirmed by analysis on a $2 \%$ agarose gel, by melting curve analysis, and by nucleotide sequencing followed by BlastX confirmation (Altschul et al. 1997). Glyceraldehyde 3 -phosphate dehydrogenase $(G A P D H)$ and $\beta$-actin were used as endogenous controls and have shown the same pattern of regulation; therefore, $G A P D H$ was chosen as the expression reference gene. GAPDH and rRNA $25 \mathrm{~S}$ are considered good reference genes for measuring the relative expression of other genes in sugarcane (Iskandar et al. 2004). The GenBank accessions used to design the primers for BBPI, sugarwinl, sugarwin2, and GAPDH were AY093805, CA145787, CA138924, and CA301409, respectively. The primer sequences used for the relative quantification can be found in Supplementary Table S2. The relative quantification was performed using a correction for primer efficiency (Pfaffl 2001). 


\section{Heterologous expression of SUGARWIN1 and SUGARWIN2 in Pichia pastoris.}

The coding regions for SUGARWIN1 and SUGARWIN2, without the signal peptide, were amplified by PCR from the clones described above. The PCR products were digested with the restriction enzyme XhoI and cloned into the pPICZ $\alpha \mathrm{A}$ vector (Invitrogen), which had been digested with the same enzyme. Next, the constructs were transformed into Escherichia coli $\mathrm{DH} 5 \alpha$ and selected in Luria-Bertani low-salt medium (1\% tryptone, $0.5 \%$ yeast extract, and $0.5 \% \mathrm{NaCl}, \mathrm{pH} 7.0$ ) supplemented with Zeocin at $25 \mu \mathrm{g} / \mathrm{ml}$. The recombinant clones were selected by PCR and verified by DNA sequencing. The pPICZ $\alpha$-SUG1 and pPICZ $\alpha$-SUG2 constructs were linearized with PmeI, and $300 \mathrm{ng}$ was used to transform Pichia pastoris KM71H competent cells, which were prepared as described by Cregg and James (2007). The competent KM71H cells were electroporated using a Gene Pulser II (Bio-Rad) with the following conditions: $1,500 \mathrm{~V}, 25 \mu \mathrm{F}$, and $200 \Omega$. The transformants were selected by plating in $1 \%$ yeast extract, $2 \%$ peptone, $2 \%$ dextrose, $1 \mathrm{M}$ sorbitol, and $2 \%$ agar medium containing zeocin at $100 \mu \mathrm{g} / \mathrm{ml}$. Several transformants of the SUG1 and SUG2 constructs were confirmed by PCR and screened for expression in a 2-ml scale using 24-deep well plates (Whatman, Maidstone, U.K.) as described by Boettner and associates (2002). Samples $(15 \mu \mathrm{l})$ of the supernatant of each culture were analyzed by sodium dodecyl sulfate polyacrylamide gel electrophoresis (SDS-PAGE), and the clones with the highest level of expression were used for recombinant protein production. A single colony of $P$. pastoris containing the sugarwinl or the sugarwin2 construct was used to inoculate $10 \mathrm{ml} 1 \%$ yeast extract, $2 \%$ peptone, $100 \mathrm{mM}$ potassium phosphate buffer (pH 7.0), 1.34\% YNB, $4 \times 10^{-5} \%$ biotin, and $1 \%$ glycerol (BMGY) that was grown at $30^{\circ} \mathrm{C}$ until an optical density (OD) at $600 \mathrm{~nm}$ of approximately 5 was reached. This culture was used to inoculate $500 \mathrm{ml}$ of BMGY that was grown to an OD of 4 to 5 . The cells were harvested by centrifugation at $1,500 \times g$ for $5 \mathrm{~min}$, resuspended in $100 \mathrm{ml}$ of BMGY with $0.5 \%$ methanol instead of glycerol, and incubated at $26^{\circ} \mathrm{C}$ for SUGARWIN1 and $30^{\circ} \mathrm{C}$ for SUGARWIN2. To induce gene expression, methanol was added to each sample every $24 \mathrm{~h}$ to maintain a final concentration of $0.75 \%$. After $96 \mathrm{~h}$, the cells were harvested by centrifugation at $1,500 \times g$ for $5 \mathrm{~min}$, and the supernatant was passed through a membrane filter of 0.45 $\mu \mathrm{m}$ (Millipore, Bedford, MA, U.S.A.). The recombinant proteins in the supernatant were purified by affinity chromatography using Ni-NTA-agarose (Qiagen) pre-equilibrated with purification buffer $\left(10 \mathrm{mM}\right.$ Tris- $\mathrm{HCl}, \mathrm{pH} 8.0 ; 50 \mathrm{mM} \mathrm{NaH}_{2} \mathrm{PO}_{4}$; and $100 \mathrm{mM} \mathrm{NaCl}$ ). After binding, the proteins were eluted with two-column volumes of purification buffer containing increased imidazole concentrations $(10,25,50,75,100$, and $250 \mathrm{mM})$. The fractions containing the SUGARWIN1 and SUGARWIN2 proteins were dialyzed in PBS $(137 \mathrm{mM} \mathrm{NaCl}, 2.7 \mathrm{mM} \mathrm{KCl}$,

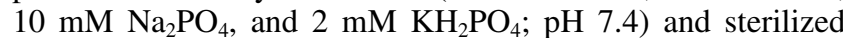
with a $0.22-\mu \mathrm{m}$ filter (Millipore). The protein concentrations were determined using the BCA protein assay kit (Pierce). The purification of both recombinant proteins was monitored using SDS-PAGE (Supplementary Fig. S1).

\section{The effect of recombinant SUGARWIN on the development of $D$. saccharalis.}

Newly hatched larvae were transferred to individual petri dishes containing a corn-based artificial diet (Parra and Mihsfeldt 1992) supplemented with $30 \%$ (vol/vol) of a solution containing recombinant SUGARWIN1 and SUGARWIN2 (in a final concentration of $420 \mu \mathrm{g} / \mathrm{ml}$ ). The negative control was the same diet supplemented with $30 \%$ (vol/ $/ \mathrm{vol})$ of PBS buffer. The diet supplemented with $5 \%$ (wt/vol) of semipurified soybean proteinase inhibitor served as positive control (Pompermayer et al. 2003) $(250 \mu \mathrm{M})$. The proteins were added to the diet when the temperature reached $40^{\circ} \mathrm{C}$ and were thoroughly mixed before pouring into individual petri dishes. The diet was allowed to rest for $30 \mathrm{~min}$ at room temperature before neonate transfer. $D$. saccharalis was reared with a photophase of $14 \mathrm{~h}$ at $25 \pm$ $4^{\circ} \mathrm{C}$ and $60 \pm 10 \%$ relative humidity. Fourteen days after transferring the larvae to the diet, larval survival and mean larval weight were evaluated. The four treatments-negative control (PBS), positive control (soybean proteinase inhibitor), SUGARWIN1 and SUGARWIN2-were arranged in a completely randomized design with an uneven number of repetitions. In total, 240 caterpillars, each one representing a single repetition, were used in the experiments, which were replicated at least twice.

\section{Viability test on $\boldsymbol{F}$. verticillioides.}

Initially, conidia of $F$. verticillioides were treated with SUGARWIN2. Approximately 10 conidia of $F$. verticillioides were inoculated into the wells of a 96-well plate containing liquid PD (potato dextrose) medium. After $8 \mathrm{~h}$ of incubation at $25^{\circ} \mathrm{C}$, SUGARWIN2 was added to each well at a final concentration of $20,40,80$, or $160 \mu \mathrm{M}$. PBS was used as a negative control. The treatments were performed in triplicate. After 16 $\mathrm{h}$ of treatment, all of the material was transferred to a 24-well plate containing solid PD medium. The plates were incubated at $25^{\circ} \mathrm{C}$ for another $36 \mathrm{~h}$.

\section{The effect of recombinant SUGARWIN2 on the mycelial morphology of $\boldsymbol{F}$. verticillioides.}

Approximately $1.5 \times 10^{4}$ conidia of $F$. verticillioides were inoculated into wells with coverslips of a 24 -well plate containing liquid PD medium. After $8 \mathrm{~h}$ of incubation at $25^{\circ} \mathrm{C}$, SUGARWIN2 was added to each well at a final concentration of $160 \mu \mathrm{M}$. The plates were incubated at $25^{\circ} \mathrm{C}$ for $16 \mathrm{~h}$. The treatments were performed in triplicate. The morphological analysis was performed at 2, 4, 6, 8, and $16 \mathrm{~h}$. PBS was used as a negative control.

\section{Microscopy of $\boldsymbol{F}$. verticillioides.}

The slides were mounted and the images were analyzed by fluorescence microscopy at room temperature. The slides were viewed with a Carl Zeiss (Jena, Germany) microscope using a $\times 100$ magnification oil-immersion objective lens using a $43 \mathrm{HE}$ DsRed filter (excitation 550/25 nm and emission 605/70) for staining with TUNEL and a 49DAPI filter (excitation $365 \mathrm{~nm}$ and emission 445/50) for staining with 4',6-diamidino-2phenylindole (DAPI) and Calcofluor. Phase contrast for the brightfield and fluorescent images was captured with an AxioCam camera (Carl Zeiss), processed using the AxioVision software version 3.1, and saved as TIFF files. Further processing was performed using Adobe Photoshop 7.0 (Adobe Systems Incorporated, San Jose, CA, U.S.A.).

\section{Calcofluor assay on $\boldsymbol{F}$. verticillioides.}

After treatment with SUGARWIN2, slides of $F$. verticillioides were mounted with the addition of $2 \mu \mathrm{l}$ of a solution of Fluorescent Brightener 28 (Calcofluor White M2R) (SigmaAldrich) at a concentration of $1 \mathrm{mg} / \mathrm{ml}$ in each sample, which remained for $10 \mathrm{~min}$ in the dark (Bertini et al. 2009). The images were acquired using a Carl Zeiss microscope using a $\times 100$ objective lens, brightfield imaging, and 49DAPI filter for staining with Calcofluor.

\section{TUNEL assay on $F$. verticillioides.}

DNA strand breaks were demonstrated by a TUNEL assay using an In Situ Cell Death Detection Kit, TMR red (Roche 
Diagnostics GmbH, Mannheim, Germany). After $16 \mathrm{~h}$ of treatment with SUGARWIN2 at $25^{\circ} \mathrm{C}$, as previously described, the supernatants containing the hyphae were transferred to microtubes and washed with PBS. The TUNEL assay was then performed as described by Madeo and associates (1997) for the yeast Saccharomyces cerevisiae, with modifications. The hyphae were first fixed with fixation solution $3.7 \%$ formaldehyde, $0.2 \%$ Tween 80 , and $50 \mathrm{mM} \mathrm{N} \mathrm{N}_{2} \mathrm{H}_{2} \mathrm{PO}_{4}$ ) for $30 \mathrm{~min}$ at room temperature and then washed in PBS. The hyphae were incubated in permeabilization solution $(0.1 \%$ Triton X-100 and $0.1 \%$ sodium citrate) for $10 \mathrm{~min}$ on ice, followed by a further washing with PBS. The hyphae were incubated with a TUNEL reaction solution for $1 \mathrm{~h}$ at $37^{\circ} \mathrm{C}$, followed by further washing with PBS. The cells were then subjected to nuclear staining for 3 min with DAPI (Sigma-Aldrich) at $0.1 \mu \mathrm{g} / \mathrm{ml}$, a fluorescent stain that binds strongly to A-T rich regions in the DNA, producing a bright blue nucleus. The images were acquired using a Carl Zeiss microscope with a $\times 100$ objective lens, brightfield imaging, and 49DAPI and 43HE DsRed filters for staining with DAPI and TUNEL, respectively.

\section{ACKNOWLEDGMENTS}

We thank S. M. Chabregas and M. C. Falco of the Centro de Tecnologia Canavieira for providing the sugarcane plantlets, D. saccharalis larvae, and fungal isolates; E. Calderan for enormous assistance with insect and fungal experiments; A. C. Santiago for technical assistance; J. Haseloff for providing the plasmid pBIN 35S-mGFP5; N. G. Zério for skillful assistance in the D. saccharalis rearing assays; A. Figueira for the real-time PCR facilities; and M. M. Brandão for the phylogenetic analyses. This work was supported by the Fundação de Amparo a Pesquisa do Estado de São Paulo (FAPESP) grant 08/52067-3, the Conselho Nacional de Desenvolvimento Científico e Tecnológico (CNPq) grant 474542/2010-6, and the Instituto Nacional de Ciência e Tecnologia do Bioetanol grant 574002/ 2008-1 and FAPESP 08/57908-6. M. C. Silva-Filho, G. H. Goldman, and F. F. Henrique-Silva are also research fellows of CNPq.

\section{LITERATURE CITED}

Abbott, E. V., and Hughes, C. G. 1961. Red rot. Pages 263-282 in: Sugarcane Diseases of the World. J. P. Martin, E. V. Abbott, and C. G. Hughes, eds. Elsevier, Amsterdam.

Agrawal, G. K., Jwa, N. S., Han, K. S., Agrawal, V. P., and Rakwal, R. 2003. Isolation of a novel rice PR4 type gene whose mRNA expression is modulated by blast pathogen attack and signaling components. Plant Physiol. Biochem. 41:81-90.

Altschul, S. F., Madden, T. L., Schaffer, A. A., Zhang, J., Zhang, Z., Miller, W., and Lipman, D. J. 1997. Gapped BLAST and PSI-BLAST: a new generation of protein database search programs. Nucleic Acids Res. 25:3389-3402.

Anisimova, M., and Gascuel, O. 2006. Approximate likelihood-ratio test for branches: A fast, accurate, and powerful alternative. Syst. Biol. 55:539-552.

Bendtsen, J. D., Nielsen, H., von Heijne, G., and Brunak, S. 2004. Improved prediction of signal peptides: SignalP 3.0. J. Mol. Biol. 340:783-795.

Bertini, L., Cascone, A., Tucci, M., D'Amore, R., Di Berardino, I., Buonocore, V., Caporale, C., and Caruso, C. 2006. Molecular and functional analysis of new members of the wheat PR4 gene family. Biol. Chem. 387:1101-1111.

Bertini, L., Caporale, C., Testa, M., Proietti, S., and Caruso, C. 2009. Structural basis of the antifungal activity of wheat PR4 proteins. FEBS (Feb. Eur. Biochem. Soc.) Lett. 583:2865-2871.

Boettner, M., Prinz, B., Holz, C., Stahl, U., and Lang, C. 2002. Highthroughput screening for expression of heterologous proteins in the yeast Pichia pastoris. J. Biotechnol. 99:51-62.

Bravo, J. M., Campo, S., Murillo, I., Coca, M., and Segundo, B. S. 2003. Fungus- and wound-induced accumulation of mRNA containing a class II chitinase of the pathogenesis-related protein 4 (PR-4) family of maize. Plant Mol. Biol. 52:745-759.

Broekaert, I., Lee, H. I., Kush, A., Chua, N. H., and Raikhel, N. 1990. Wound-induced accumulation of mRNA containing a hevein sequence in laticifers of rubber tree (Hevea brasiliensis). Proc. Natl. Acad. Sci. U.S.A. 87:7633-7637.

Caruso, C., Bertini, L., Tucci, M., Caporale, C., Leonardi, L., Saccardo, F.,
Bressan, R. A., Veronese, P., and Buonocore, V. 1999. Isolation and characterisation of wheat cDNA clones encoding PR4 proteins. DNA Seq. 10:301-307.

Caruso, C., Bertini, L., Tucci, M., Caporale, C., Nobile, M., Leonardi, L., and Buonocore, V. 2001. Recombinant wheat antifungal PR4 proteins expressed in Escherichia coli. Protein Expr. Purif. 23:380-388.

Christopher, M. E., Miranda, M., Major, I. T., and Constabel, C. P. 2004. Gene expression profiling of systemically wound-induced defenses in hybrid poplar. Planta 219:936-947.

Cregg, J. M. 2007. Methods in Molecular Biology.

Cui, J., Jander, G., Racki, L. R., Kim, P. D., Pierce, N. E., and Ausubel, F. M. 2002. Signals involved in Arabidopsis resistance to Trichoplusia ni caterpillars induced by virulent and avirulent strains of the phytopathogen Pseudomonas syringae. Plant Physiol. 129:551-564.

Dangl, J. L., and Jones, J. D. 2001. Plant pathogens and integrated defence responses to infection. Nature 411:826-833.

De Nooij, M. P., Biere, A. and Linders, E. G. A. 1992. Pest and pathogen interactions through host predisposition. Pages 143-160 in: Pests and Pathogens: Plant Responses to Foliar Attack. P. G. Ayres, ed. BIOS Scientific, Oxford.

De Vos, M., Van Zaanen, W., Koornneef, A., Korzelius, J. P., Dicke, M., Van Loon, L. C., and Pieterse, C. M. 2006. Herbivore-induced resistance against microbial pathogens in Arabidopsis. Plant Physiol. 142:352-363.

Duby, G., Degand, H., and Boutry, M. 2001. Structure requirement and identification of a cryptic cleavage site in the mitochondrial processing of a plant F1-ATPase beta-subunit presequence. FEBS (Feb. Eur. Biochem. Soc.) Lett. 505:409-413.

Edgar, R. C. 2004. MUSCLE: Multiple sequence alignment with high accuracy and high throughput. Nucleic Acids Res. 32:1792-1797.

Falco, M. C., Marbach, P. A. S., Pompermayer, P., Lopes, F. C. C., and Silva-Filho, M. C. 2001. Mechanisms of sugarcane response to herbivory. Genet. Mol. Biol. 24:113-122.

Friedrich, L., Moyer, M., Ward, E., and Ryals, J. 1991. Pathogenesis-related protein- 4 is structurally homologous to the carboxy-terminal domains of hevein, win-1 and win-2. Mol. Gen. Genet. 230:113-119.

Gatch, E. W., and Munkvold, G. P. 2002. Fungal species composition in maize stalks in relation to European corn borer injury and transgenic insect protection. Plant Dis. 86:1156-1162.

Green, T. R., and Ryan, C. A. 1972. Wound-induced proteinase inhibitor in plant leaves: a possible defense mechanism against insects. Science 175:776-777.

Grivet, L., and Arruda, P. 2002. Sugarcane genomics: depicting the complex genome of an important tropical crop. Curr. Opin. Plant Biol. 5:122-127.

Guindon, S., and Gascuel, O. 2003. A simple, fast, and accurate algorithm to estimate large phylogenies by maximum likelihood. Syst. Biol 52:696-704.

Haseloff, J., Siemering, K. R., Prasher, D. C., and Hodge, S. 1997. Removal of a cryptic intron and subcellular localization of green fluorescent protein are required to mark transgenic Arabidopsis plants brightly. Proc. Natl. Acad. Sci. U.S.A. 94:2122-2127.

Hejgaard, J., Jacobsen, S., Bjorn, S. E., and Kragh, K. M. 1992. Antifungal activity of chitin-binding PR-4 type proteins from barley grain and stressed leaf. FEBS (Feb. Eur. Biochem. Soc.) Lett. 307:389-392.

Howe, G. A., Lightner, J., Browse, J., and Ryan, C. A. 1996. An octadecanoid pathway mutant (JL5) of tomato is compromised in signaling for defense against insect attack. Plant Cell 8:2067-2077.

Iskandar, H. M., Simpson, R. S., Casu, R. E., Bonnett, G. D., MacLean, D. J., and Manners, J. M. 2004. Comparison of reference genes for quantitative real-time polymerase chain reaction analysis of gene expression in sugarcane. Plant Mol. Biol. Rep. 22:325-337.

Karban, R., and Baldwin, I. T. 1997. Induced Responses to Herbivory. Chicago University Press, Chicago.

Kessler, A., and Baldwin, I. T. 2002. Plant responses to insect herbivory: the emerging molecular analysis. Annu. Rev. Plant Biol. 53:299-328.

Khanna, K. L., and Rafay, S. A. 1953. Annual report of the scheme for the investigation and control of wilt disease of sugar cane for the year ending 3rd May 1953. Central Sugarcane Research Station, Bihar, India.

Kiba, A., Saitoh, H., Nishihara, M., Omiya, K., and Yamamura, S. 2003. C-terminal domain of a hevein-like protein from Wasabia japonica has potent antimicrobial activity. Plant Cell Physiol. 44:296-303.

Li, X., Xia, B., Jiang, Y., Wu, Q., Wang, C., He, L., Peng, F., and Wang, R. 2010. A new pathogenesis-related protein, LrPR4, from Lycoris radiata, and its antifungal activity against Magnaporthe grisea. Mol. Biol. Rep. 37:995-1001

Linthorst, H. J. M., Danhash, N., Brederode, F. T., Vankan, J. A. L., Dewit, P. J. G. M., and Bol, J. F. 1991. Tobacco and tomato PR proteins homologous to win and pro-hevein lack the hevein domain. Mol. PlantMicrobe Interact. 4:586-592. 
Lukaszewicz, M., Jerouville, B., and Boutry, M. 1998. Signs of translational regulation within the transcript leader of a plant plasma membrane H+-ATPase gene. Plant J. 14:413-423.

Madeo, F., Frohlich, E., and Frohlich, K.U. 1997. A yeast mutant showing diagnostic markers of early and late apoptosis. J. Cell Biol. 139:729734.

McFarlane, S. A., Govender, P., and Rutherford, R. S. 2009. Interactions between Fusarium species from sugarcane and the stalk borer, Eldana saccharina (Lepidoptera: Pyralidae). Ann. Appl. Biol. 155:349-359.

McKaig, N. 1936. Chemical composition of juice from Louisiana sugarcane injured by the sugarcane borer and the red rot disease. J. Agric. Res. 52:0017-0025.

Mian, A. A., Coates, J., and Cordiner, J. B. 1969. Binary gaseous diffusion coefficients of N2-Hcl, a-Hbr and N2-Hbr systems as a function of temperature. Can. J. Chem. Eng. 47:499.

Moura, D. S., and Ryan, C. A. 2001. Wound-inducible proteinase inhibitors in pepper. Differential regulation upon wounding, systemin, and methyl jasmonate. Plant Physiol. 126:289-298.

Ogunwolu, E. O., Reagan, T. E., Flynn, J. L., and Hensley, S. D. 1991. Effects of Diatraea saccharalis (F) (Lepidoptera, Pyralidae) damage and stalk rot fungi on sugarcane yield in Louisiana. Crop Prot. 10:57-61.

Parra, J. R. P., and Mihsfeldt, L. H. 1992. Comparison of artificial diets for rearing the sugarcane borer. Pages 195-209 in: Advances in Insect Rearing for Research and Pest Management T. A. N. Leppla, ed. Westview Press, Boulder, CO, U.S.A.

Pfaffl, M. W. 2001. A new mathematical model for relative quantification in real-time RT-PCR. Nucleic Acids Res. 29:e45. Published online.

Pfaffl, M. W., Horgan, G. W., and Dempfle, L. 2002. Relative expression software tool (REST (c)) for group-wise comparison and statistical analysis of relative expression results in real-time PCR. Nucleic Acids Res. 30:e36. Published online.

Pompermayer, P., Falco, M. C., Parra, J. R. P., and Silva-Filho, M. C. 2003. Coupling diet quality and Bowman-Birk and Kunitz-type soybean proteinase inhibitor effectiveness to Diatraea saccharalis development and mortality. Entomol. Exp. Appl. 109:217-224.

Reymond, P., Bodenhausen, N., Van Poecke, R. M., Krishnamurthy, V., Dicke, M., and Farmer, E. E. 2004. A conserved transcript pattern in response to a specialist and a generalist herbivore. Plant Cell 16:31323147.

Quevillon, E., Silventoinen, V., Pillai, S., Harte, N., Mulder, N., Apweiler, R., and Lopez, R. 2005. InterProScan: protein domains identifier Nucleic Acids Res. 33:W116-W120.

Ryan, C. A. 1968. An inducible protein in potato and tomato leaflets. Plant Physiol. 43:1880-1881.

Ryan, C. A. 1990. Protease Inhibitors in plants-genes for improving defenses against insects and pathogens. Annu. Rev. Phytopathol. 28:425449
Ryan, C. A. 2000. The systemin signaling pathway: differential activation of plant defensive genes. BBA-Protein Struct. M 1477:112-121.

Schilmiller, A. L., and Howe, G. A. 2005. Systemic signaling in the wound response. Curr. Opin. Plant Biol. 8:369-377.

Scott, A., Wyatt, S., Tsou, P. L., Robertson, D., and Allen, N. S. 1999. Model system for plant cell biology: GFP imaging in living onion epidermal cells. Biotechniques 26:1125, 1128-1132.

Singh, K., Budhraja, T. R., and Agnihotri, V. P. 1977. Survival of Colletotrichum falcatum in soil, its portals of entry and role of inoculum density in causing infection. Int. Sugar J. 79:43-44.

Stout, M. J., Fidantsef, A. L., Duffey, S. S., and Bostock, R. M. 1999. Signal interactions in pathogen and insect attack: systemic plant-mediated interactions between pathogens and herbivores of the tomato, Lycopersicon esculentum. Physiol. Mol. Plant Pathol. 54:115-130.

Svensson, B., Svendsen, I., Hojrup, P., Roepstorff, P., Ludvigsen, S., and Poulsen, F. M. 1992. Primary structure of barwin: a barley seed protein closely related to the C-terminal domain of proteins encoded by woundinduced plant genes. Biochemistry 31:8767-8770.

Upadhyay, R. K., Mukerji, K. G., Chamola, B. P., and Dueby, O. P. 2009. Integrated Pest and Disease Management. APH Publishing Corporation, New Delhi, India.

Vettore, A. L., da Silva, F. R., Kemper, E. L., and Arruda, P. 2001. The libraries that made SUCEST. Genet. Mol. Biol. 24:1-7.

Vettore, A. L., da Silva, F. R., Kemper, E. L., Souza, G. M., da Silva, A. M., Ferro, M. I., Henrique-Silva, F., Giglioti, E. A., Lemos, M. V., Coutinho, L. L., Nobrega, M. P., Carrer, H., Franca, S. C., Bacci Junior, M., Goldman, M. H., Gomes, S. L., Nunes, L. R., Camargo, L. E., Siqueira, W. J., Van Sluys, M. A., Thiemann, O. H., Kuramae, E. E., Santelli, R. V., Marino, C. L., Targon, M. L., Ferro, J. A., Silveira, H. C., Marini, D. C., Lemos, E. G., Monteiro-Vitorello, C. B., Tambor, J. H., Carraro, D. M., Roberto, P. G., Martins, V. G., Goldman, G. H., de Oliveira, R. C., Truffi, D., Colombo, C. A., Rossi, M., de Araujo, P. G., Sculaccio, S. A., Angella, A., Lima, M. M., de Rosa Junior, V. E., Siviero, F., Coscrato, V. E., Machado, M. A., Grivet, L., Di Mauro, S. M., Nobrega, F. G., Menck, C. F., Braga, M. D., Telles, G. P., Cara, F. A., Pedrosa, G., Meidanis, J., and Arruda, P. 2003. Analysis and functional annotation of an expressed sequence tag collection for tropical crop sugarcane. Genome Res. 13:2725-2735.

Walling, L. L. 2000. The myriad plant responses to herbivores. J. Plant Growth Regul. 19:195-216.

Wu, J., Baldwin, I. T. 2009. Herbivory-induced signalling in plants: perception and action. Plant Cell Environ. 32:1161-1174.

Wu, J. Q., and Baldwin, I. T. 2010. New insights into plant responses to the attack from insect herbivores. Annu. Rev. Genet. 44:1-24.

Zhu, T., Song, F., and Zheng, Z. 2006. Molecular characterization of the rice pathogenesis-related protein, OsPR-4b, and its antifungal activity against Rhizoctonia solani. J. Phytopathol. 154:378-384. 